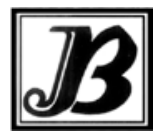

J. Bio-Sci. 23: 39-46, 2015

ISSN 1023-8654

http://www.banglajol.info/index.php/JBS/index

\title{
EFFECT OF THERMAL STIMULATION ON GONAD MATURATION IN SEA CUCUMBER PHYLLOPHORUS SP. (GRUBE, 1840)
}

\author{
S Andriyono ${ }^{1,2 *}, \mathrm{~N}^{2}$ Masruroh ${ }^{3}$, ED Masithah ${ }^{2}, \mathrm{~J}$ Triastuti2 and D Winarni ${ }^{4}$ \\ IInterdisciplinary Program of Biomedical, Mechanical and Electrical Engineering, Pukyong National \\ University, Busan, 48513, Republic of Korea; ${ }^{2}$ Department of Marine; ${ }^{3}$ Aquaculture Program \\ and ${ }^{4}$ Department of Biology, Faculty of Science and Technology, Universitas Airlangga, Campus C UNAIR \\ Jl. Mulyorejo, Surabaya, 601145, Indonesia
}

\begin{abstract}
Sea cucumbers, marine animals from the class Holothuroidea, have been widely known as fishery products for consumption in Indonesia. The Madura Strait is productive waters for sea cucumbers in eastern Indonesia, including sea cucumber species Phyllophorus sp. The exploitation of it mainly for consumption even though there are pharmaceutical beneficial of sea cucumber already known. The study of temperature effect is ideal inducement method for sea cucumber, but less research about this stimulation for Phyllophorus sp. for domestication purposes. The research showed that thermal stimulation treatment at the temperature of $30^{\circ} \mathrm{C}, 32^{\circ} \mathrm{C}$ and $34^{\circ} \mathrm{C}$ were in contrast to the that of control histological analysis proof that some of Phyllophorus sp. showed altered levels of gonadal maturation toward growth and advanced growth phase after thermal stimulation, respectively. The ideal stimulation treatment for gonad maturation was shown with stimulated temperature treatment of $32^{\circ} \mathrm{C}$.
\end{abstract}

Key words: Frequency, histology, Phyllophorus sp., sea cucumbers, thermal stimulation

\section{Introduction}

As one of the popular invertebartes fishery products, sea cucumbers from the class Holothuroidea have long been consumed by Indonesians (Pangkey et al. 2012). The marine ecosystem along Madura Strait, including Surabaya, is productive for sea cucumbers species in eastern part of Java Island in Indonesia. One of the highly abundant species is Phyllophorus sp. which is not included in the list of commercial sea cucumber in the global market (Purnama and Winarni 2017) and Paracaudina australis (Widianingsih et al. 2018). Intensive exploitation of sea cucumbers Phyllophorus sp. only used as food in the form of sea cucumber chips. The demand for this product is quite high so that the population of sea cucumbers Phyllophorus sp. in nature is very limited in certain seasons. Some research found active compound and the pharmaceutical ingredients from this sea cucumber such as triterpene glycoside, chondroitin sulfates, and others active compound (Revianti et al. 2016).

Regarding the potential value of sea cucumbers, the cultivation and domestication activities of some sea cucumbers need to be conducted. The sea cucumber culture especially Phyllophorus sp. species, not yet done because of the lack of biological information and various efforts in the conservation strategy. The use thermal stimulation for sea cucumber reproduction is not a novelty (James et al. 1994), but for this species are still very important in providing information related to the breeding characteristics of Phyllophorus sp. Various spawning stimulation techniques on sea cucumber have been applied and thermal stimulation techniques done by raising the temperature for $3-5^{\circ} \mathrm{C}$ from the optimal temperature of $28^{\circ} \mathrm{C}$ is regarded as

*Author for correspondence: sapto.andriyono@fpk.unair.ac.id 
the most effective (Pitt 2001). The thermal stimulation (ambient temperature of $\pm 3-5^{\circ} \mathrm{C}$ ) has gained success in initiating spawning on Holothuria scabra (Kumara et al. 2013). Accordingly, this study conducted thermal stimulation on sea cucumbers of Phyllophorus sp. aimed at revealing the ideal temperature affect to the gonad maturity by observing the sea cucumber gonadal histology.

\section{Materials and Methods}

\section{Samples collection}

This study utilized sea cucumber Phyllophorus sp. from the East Coast of Surabaya, Indonesia. Sea cucumbers were taken freely during low tide in order to avoid currents and waves and facilitate sampling with some modification (Conan 1993). Sea cucumbers collected were put into $60 \times 80 \mathrm{~cm}^{2}$ plastic bags with each containing of 15 individuals. Further handling for brood stock, mud from habitat was added to cover the entire body of sea cucumbers and a rubber band was then tied around each bag without addition of oxygen. The method of packing sea cucumbers packing was adapted from preliminary study. Subsequently, sea cucumbers were transported to the Educational Laboratory of the Faculty of Fisheries and Marine Science, Universitas Airlangga. Morphological gonads between male and female sea cucumber were analyses directly based on color and some granules (Fig. 1). Female sea cucumbers Phyllophorus sp. gonad was moss green in color with bulging and branching tubules, than male sea cucumbers Phyllophorus sp. gonad showed a yellowish white color with branching tubules.
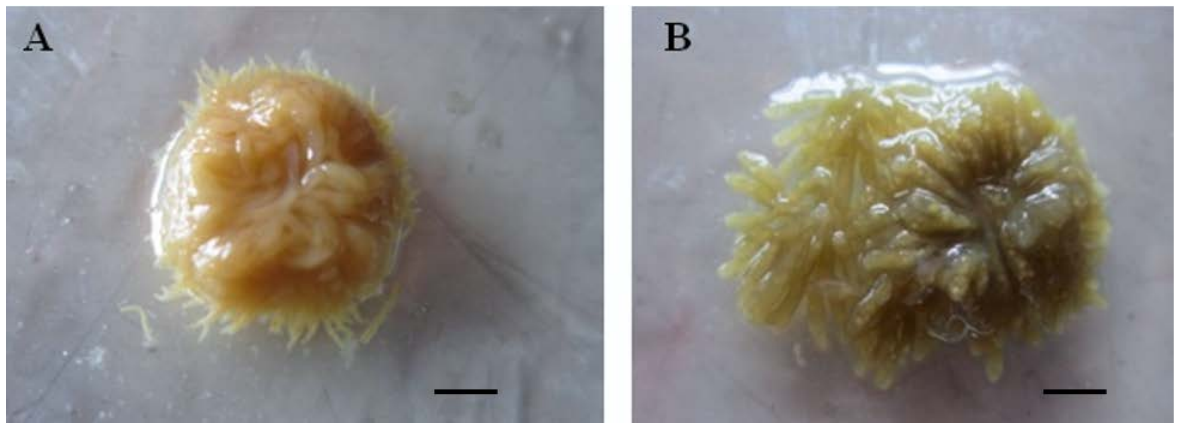

Fig. 1. Morphology of sea cucumber Phyllophorus sp. male gonad (A) and female gonad (B). Scale bar 5 $\mathrm{mm}$.

\section{Thermal stimulation}

Before getting thermal stimulation difference treatment, sea cucumber keep in the culture 10 liter medium for 15 days until SR more than $80 \%$ with sea cucumber density is 1 individual/2 liter water. The water in the plastic container was changed everyday and added aeration for dissolved oxigent maintain in suitable condition. The fresh marine micro algae was given for sea cucumber food. Ten sea cucumber were kept in aech container. This survival rate as indicator for sea cucumber adaptation to the new habitat. The treatments used in this study is thermal stimulation with ambient water temperature at $28^{\circ} \mathrm{C}, 30^{\circ} \mathrm{C}, 32^{\circ} \mathrm{C}$ and $34^{\circ} \mathrm{C}$. Increasing $3-5^{\circ} \mathrm{C}$ for thermal stimulation was enough to artificial sea cuumber spawning in tank (James et al. 1994, Laxminarayana 2005, Dabbagh and Sedaghat 2012). Twelve plastic containers with a capacity of 10 liter were prepared and then filled with sea water. In order to obtain the temperature of $30^{\circ} \mathrm{C}$, $32^{\circ} \mathrm{C}$ and $34^{\circ} \mathrm{C}$, each container was equipped with a heater that has been set with specified temperature. Furthermore, sea cucumbers were inserted into the plastic container. The length of thermal stimulation 
ranging from 30-60 minutes each is deemed sufficient to affect the gonads of sea cucumbers (Agudo 2006, Ivy and Giraspy 2006). In this study, thermal stimulation was conducted for 60 minutes (Battaglene et al. 2002). Upon stimulation, sea cucumbers were placed into a plastic container with sea water at normal temperature $\left(28^{\circ} \mathrm{C}\right)$ for $1-1.5$ hours until they show changes in behavior as characterized by the upward movement of the male parent to the tub wall (Laxminarayana 2005).

\section{Histology}

Gonadal histology was performed by means of fixating the gonads in a liquid solution of neutral buffered formalin fixative for more than 24 hours. Gonad preserved in buffer formalin were rinse in aquades and than sore in $70 \%$ etanol. For further histology, five tubules of each gonad were taken for further processing that involved several phases. The first step are dehydrated, embedded in paraffin, sectioned to get $6 \mu \mathrm{m}$ thick every layer then affixed, and at last stained with haemotoxylin and eosin (H/E) (Romafafia et al. 2000, Mumford 2004). Five longitudinal cuts were made acros tubules, and results of gonadal histology were further observed under a microscope with 100x magnification and then documented.

\section{Data analysis}

The data were analyzed descriptively to illustrate the effect of thermal stimulation on the gonadal histology of sea cucumbers Phyllophorus sp. Gonad maturity index (GMI) are comparison between body tissue and gonad ratios commonly use for measure reproctuctive periodicity (Morgan 2000) or in the other word that GMI is a value obtained from the ratio of gonad dimensions (weight, volume or area) with a specific organ, such as the integument either complete or without visceral organs and body-wall weight (Tuwo 1999). Water quality was measured to ensure water condition along thermal stimulation and sea cucumber rearing periods including salinity, disolved oxygent and water acidity (pH level).

\section{Results}

\section{Sea cucumbers Phyllophorus sp. of GMI}

Thermal stimulation at the temperature of $30^{\circ} \mathrm{C}, 32^{\circ} \mathrm{C}$ and $34^{\circ} \mathrm{C}$ have significant than control temperature of $28^{\circ} \mathrm{C}$ based on GMI. Gonadal maturity index of sea cucumbers Phyllophorus sp. is highest in treatment $\mathrm{C}$ $\left(32^{\circ} \mathrm{C}\right)$ with an average index of $12.29 \%$, while the lowest was treatment $\mathrm{D}\left(34^{\circ} \mathrm{C}\right)$ with an average index of $6.61 \%$. While the treatment of $A\left(28^{\circ} \mathrm{C}\right)$ and $B\left(30^{\circ} \mathrm{C}\right)$ did not differ significantly that is $10.0 \%$ to $10.5 \%$ respectively.

\section{Gonadal histology of sea cucumbers of Phyllophorus sp.}

Histological examination of the gonads of sea cucumbers was conducted to determine the level of gonad maturity of each individual. Some sea cucumbers Phyllophorus sp. given thermal stimulation treatment showed altered levels of gonadal maturation toward an advanced growth phase (Table 1).

Table 1. Gonad maturity level based on gonadal histology of sea cucumbers Phyllophorus sp.

\begin{tabular}{lccccc}
\hline Gonad maturity level (\%) & \multicolumn{3}{c}{ Thermal stimulation temperature } & Survival rate \\
\cline { 2 - 5 } & $28^{\circ} \mathrm{C}$ & $30^{\circ} \mathrm{C}$ & $32^{\circ} \mathrm{C}$ & $34^{\circ} \mathrm{C}$ & $(\%)$ \\
\hline Growth & 66.67 & 33.33 & 0 & 33.33 & 100 \\
Advanced growth & 33.33 & 66.67 & 100 & 66.67 & 100 \\
\hline
\end{tabular}

Thermal stimulation treatment at $28^{\circ} \mathrm{C}$ (as the Control) indicated growth phase with a percentage of $66.67 \%$ and advanced growth phase of $33.33 \%$. Thermal stimulation treatment $30^{\circ} \mathrm{C}$ showed advanced growth 
phase of growth higher than control with the percentage of $66.67 \%$ and growth phase of $33.33 \%$. Thermal stimulation treatment on $32^{\circ} \mathrm{C}$ suggested advanced growth phase of $100 \%$ and $0 \%$ growth phase. Meanwhile, thermal stimulation treatment on $34^{\circ} \mathrm{C}$ signified advanced growth phase with the percentage of $66.67 \%$ and growth phase of $33.33 \%$. As a result, thermal stimulation treatment at the temperature of $30^{\circ} \mathrm{C}$, $32^{\circ} \mathrm{C}$ and $34^{\circ} \mathrm{C}$ was in contrast to thermal stimulation treatment at control temperature in terms of the level of gonad maturity. In all treatments, the survival rate reached $100 \%$. This signified that the media at the time of treatment is in a viable condition for holding sea cucumber Phyllophorus sp. The male and female ratio in every container cannot be determined because of the difficulty of distinguishing males and females based on morphology. At the control treatment with temperature $28^{\circ} \mathrm{C}$, found 3 males and 6 females. While the treatment temperature of $30^{\circ} \mathrm{C}$ and $32^{\circ} \mathrm{C}$, mostly dominated by females as much as 9 and 8 , while the rest are male. At the last treatment at $34^{\circ} \mathrm{C}$, male and female compositions were found to be approximately equal to 6 females and 4 males, respectively.

The males in growth phase still had a fairly thick tubular wall, and spermatogenic cells appeared to progress towards the lumen. Meanwhile, the females in growth phase had a very thick tubular wall, and a few previtellogenic oocytes detected near the walls of the tubules and the lumen was filled with vitellogenic oocytes and post vitellogenic oocytes. The males had a fairly thick tubular wall, and the lumen contained spermatozoa in advanced growth phase, than female gonads had a curved and thin tubular wall with a previtellogenic oocyte near the walls of the tubules, and vitellogenic as well as post vitellogenic oocytes in the lumen (Fig. 2-3).
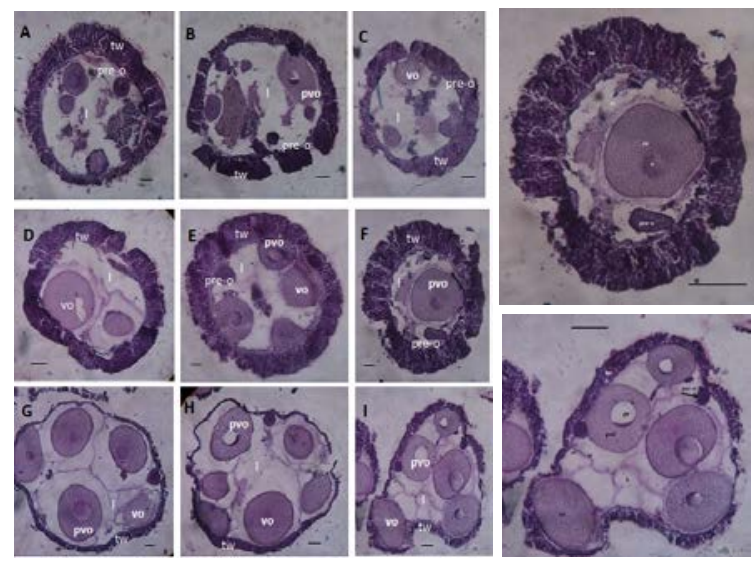

Fig. 2. Female gonad in different maturity level, growth (A-F) and advanced growth (G-H) information symboln: nucleus; ro: relict oocyte; zr: zona radiata; gv: germinal vesicle; pre-0: previtellogenic oocyte; vo: vitellogenic oocyte; pvo: post-vitellogenic oocyte; tw: tubular wall (bar $200 \mu \mathrm{m}$ ). 


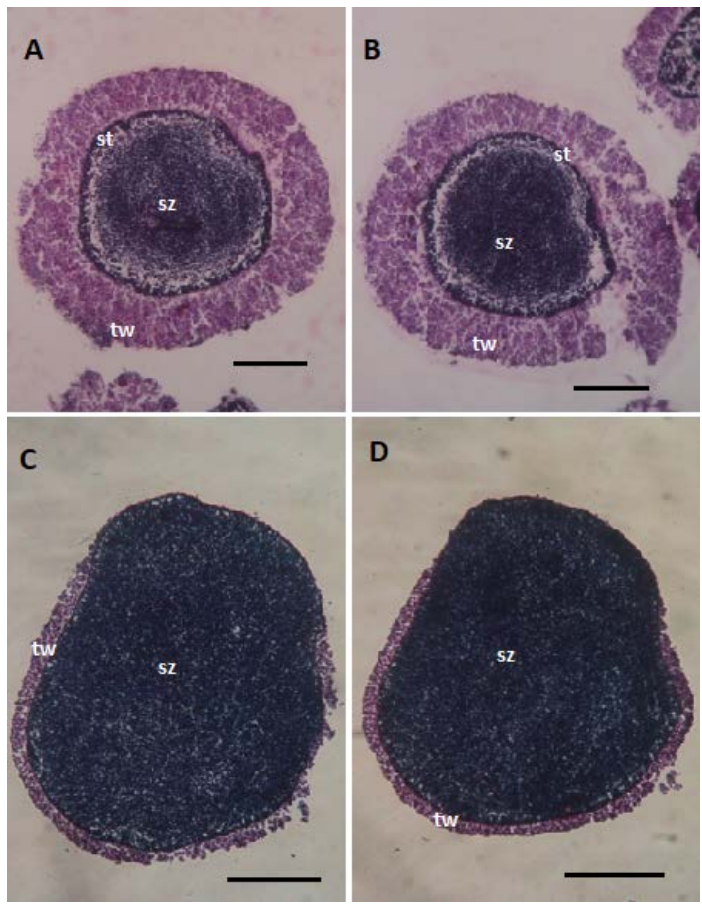

Fig. 3. The male gonad in growth pase (A-B) and advanced growth (C-D). tw: tubular wall; sz: spermatozoa; st: spermatid.

\section{Water quality maintenance on captive medium}

Water quality parameters measured include $\mathrm{pH}$, salinity, and dissolved oxygen (DO). Water quality measurement during the study was conducted at $07.00 \mathrm{pm}$. Data on the water quality during maintenance of sea cucumbers Phyllophorus sp. showed a similar average value for each container with $\mathrm{pH}$ value of 7.00 , salinity is $30 \mathrm{ppt}$, and DO at $7 \mathrm{ppm}$.

\section{Discussion}

The sea cucumbers Phyllophorus sp. is dioceous in nature or having separate sexes. Mostly the tropical sea cucumber are often high in fecundity (Laximinarayana 2005). Male and female individuals cannot be distinguished by external morphology but by observing the shape and color of the gonads, instead. Reproductive organs of sea cucumbers Phyllophorus sp. are very simple and consist of many tubules. The gonads of sea cucumbers are in the form of tubules (a tubular body), either plain, notched or forked (Purwati and Luong-Van 2003). They are mostly located in the anterior part of the body cavity. Sexual development generally results in lengthening the tubules, multiplying the branches and thinnning the tubular wall. This gonad morphological almost same to the other of Holothurians (Romafafia et al. 2000). In this study, histological analysis also revealed that thermal stimulation on sea cucumber Phyllophorus sp. higher than ambient water themperature resulted in better level of gonad maturity of broodstock Phyllophorus $\mathrm{sp}$. However, this is not supported by gonad maturity index value. There are two common problems in using gonad maturity index. Firstly, there is a possibility that during the growth phase of an animal, the size of the 
gonads is no longer proportional to its body size and the secondly, difficulties in obtaining accurate data on body weight often arise due to the damage at the time of collection (Purwati and Luong-Van 2003).

Histological studies on the gonads denoted some variations in gonadal maturity level among individuals. Thermal stimulation treatment is commont methode for artificial breeding in hatchery (James et al. 1994). However, this type of sea cucumber Phyllophorus sp. hatchery activity has never been done due to face various biological and technical obstacles (Tuwo 2005). Research on the development of gonad sea cucumbers indicates that there are monthly changes. The most common type of oocytes in the gonadal tubule lumen of Phyllophorus sp. in April was pre-vitellogenic oocytes with the percentage of $48.13 \%$ (Winarni et al. 2015). Therefore, it was predicted that in April sea cucumbers Phyllophorus sp. are in growth phase Variation in the level of gonad maturity histologically was also supported by gonad maturity index calculations for each treatment. This affirmed that stimulation at different temperatures affected the level of gonad maturity of Phyllophorus sp. In addition, variation in the level of gonad maturity of sea cucumbers Phyllophorus sp. also shows that the population of Phyllophorus sp. has an asynchronous pattern of reproduction. Population with an asynchronous pattern reproduction may spawn throughout the year. Holothuria scabra was present of maturity level (stage IV) and spawns continosly along a year (Tuwo 1999), with the peak of spawning period occurs at certain times and may vary depending on environmental changes (Conan 1993). The temperature is the most influential factor in the sexual reproduction of sea cucumbers act since it plays a role in controlling gonad maturity during spawning (Battaglene et al. 2002). External stimuli from the environment received by radial nerves will be responded by controlling the release of internal stimuli in the form of radial nerve factor (also called gonad-stimulating substance), which is similar to gonadotropin releasing factor in vertebrates (Dubois et al. 2002). In dry season, water themperatur increase and stimulating reproduction of several sea cucumber (Tuwo 1999).

In accordance with our finding that thermal stimulation at $32^{\circ} \mathrm{C}$ is the suitable thermal stimulation, supported another finding on other sea cucumbers Holothuria edulis to spawn more than $90 \%$ (Yudiati et al. 2001). Stimulation conducted by raising water temperature $3-5^{\circ} \mathrm{C}$ above the normal water temperature is also an effective method to induce spawning on sea cucumber Stichopus japonicus, which is characterized by the spawning of Stichopus japonicus egg and sperm in the water column (Chen 2003). Conducting this kind of stimulation for an hour is regarded as the most common artificial spawning stimulation technique used in the sea cucumber Holothuria scabra, which is characterized by the spawning of sea cucumbers Holothuria scabra in Solomon Island. Mature gonads of sea cucumbers will also spawn spontaneously during collection or during transport due to stress (Battaglene 1999). Thermal stimulation treatment suggested the best stimulation temperature at $32^{\circ} \mathrm{C}$, which was regarded as the optimum temperature for the growth of sea cucumber gonad parent Phyllophorus sp. The growth phase in male gonads is denoted by relatively thick walls of the tubules and curved germinal epithelium (Morgan 2000). Spermatogonia is along the surface of the germinal epithelium, and there is a layer of spermatocytes and spermatozoa cells in the middle of the lumen. The histology of the gonads on growth phase is characterized by relatively thick gonadal tubule wall in Phyllophorus sp., and spermatogenic cells that can be differentiated into spermatocytes, spermatids, and spermatozoa. In the advanced growth phase, male gonads have a thick tubular wall and lumen containing spermatozoa (Winarni et al. 2015). The wall in male gonads is thinning. The male tubules were filled with spermatozoa cells, yet spermatocyte cells may also be detected around the tubular wall. In the female gonads, the growth phase is characterized by a very thick tubular wall, and the existence of a pre-vitellogenic oocytes, vitellogenic oocytes and post vitellogenic oocytes. Ovary development is characterized by an increase in oocyte diameter as a result of the accumulation of vitellogenic during the vitellogenesis process (Romafafia et al. 2003). Vitellogenesis in female may have positip correlation with the metabolic activity and oxygent consumtion and demand (Hamel et al. 1993). Combination of environment paramater such as 
photoperiod, water themperatur and food availability may generate the process of vitelogenesis and gamatogenesis during reproduction cycles of Holothuria scabra (Morgan 2000).

Due to this activity is relatifly new in Indonesia especially for sea cucumber Phylophorus sp. This is very different from the characteristics of the Holothurian sea cucumber that has been successfully breed in Indonesia such as Holothuria scabra (Darsono 1999, Hartati 2001). One, limited reference and biological information regarding Phylophorus sp. in Indonesia coupled with a low interest in research on unknown species. Utilization of sea cucumber is still limited as food in the form of chips that are easy to process as well as the demand by the community. However, we think that information related to biological reproduction of Phylloporus sp. will be very useful especially to increase the value added of sea cucumber product not only as food but for the pharmaceutical resource.

\section{Conclusion}

We can be concluded that thermal stimulation on sea cucumber Phyllophorus sp. affected the level of maturity of the gonads and the ideal temperature to give the best effect on the gonad maturation of sea cucumbers Phyllophorus sp. was $32^{\circ} \mathrm{C}$. The thermal stimulation can be conducted to increase the level of gonad maturity within 60 minutes for stimulation. This research will be helpful for further research on sea cucumber domestication and reproduction biology, so that further related research still needed such as endocrinology during given of the thermal stimulation and stress level.

\section{Acknowledgement}

We would like to express our gratitude to the Ministry of Education, through the Directorate General of Higher Education that provides research grants with the scheme of Decentralisation of Higher Education Research 2014. We also grateful for the Indonesian Endowment Fund for Education (LPDP) scholarship under Beasiswa Unggulan Dosen Indonesia-Luar Negeri (BUDI-LN) batch I 2016 (Number: PRJ-3635 /LPDP.3/2016).

\section{References}

Agudo N (2006). Sandfish Hatchery Techniques: Secretariat of the Pacific Community.1-43 pp.

Battaglene S (1999). Culture of tropical sea cucumbers for stock restoration and enhancement. Naga, The ICLARM Quarterly 22(4): 4-11.

Battaglene SC, Seymour JE, Ramofafia C and Lane I (2002). Spawning induction of three tropical sea cucumbers, Holothuria scabra, H. fuscogilva and Actinopyga mauritiana. Aquaculture 207(1): $29-47$.

Chen J (2003). Overview of sea cucumber farming and sea ranching practices in China. SPC Beche-de-Mer Information Bulletin 18: 18-23.

Conand C (1993). Ecology and reproductive biology of Stichopus variegatus an Indo-Pacific coral reef sea cucumber (Echinodermata: Holothuroidea). Bulletin of Marine Science 52(3): 970-981.

Dabbagh AR and Sedaghat MR (2012). Breeding and rearing of the sea cucumber Holothuria scabra in Iran. SPC Beche-de-Mer Information Bulletin (32): 49-52.

Darsono P (1999). Perkembangan pembenihan teripang pasir, Holothuria scabra Jaeger, di Indonesia: Oseana. Vol. XXIV (3): 35-45.

Dubois E, Zandbergen M, Peute J and Th HG (2002). Evolutionary development of three gonadotropin-releasing hormone (GnRH) systems in vertebrates. Brain Research Bulletin 57(3-4): 413-418.

Hartati R (2001). Teknologi pembenihan teripang putih (Holothuria scabra). 
Hamel JF, Himmelman JH and Dufresne L (1993). Gametogenesis and spawning of the sea cucumber Psolus fabricii (Duben and Koren). The Biological Bulletin 184(2): 125-143.

Ivy $G$ and Giraspy DAB (2006). Development of large-scale hatchery production techniques for the commercially important sea cucumber Holothuria scabra veriscolor (Conand, 1986) in Queensland, Australia. SPC Beche-de-Mer Information Bulletin (24): 28-34.

James D, Gandhi A, Palaniswamy N and Rodrigo JX (1994). Hatchery techniques and culture of the sea-cucumber Holothuria scabra. CMFRI Special Publication 57: 1-40.

Kumara PA, Jayanatha J, Pushpakumara J, Bandara W and Dissanayake D (2013). Artificial breeding and larval rearing of three tropical sea cucumber species-Holothuria scabra, Pseudocolochirus violaceus and Colochirus quadrangularis-in Sri Lanka. SPC Beche-de-Mer Information Bulletin 33: 30-37.

Laxminarayana A (2005). Induced spawning and larval rearing of the sea cucumbers, Bohadschia marmorata and Holothuria atra in Mauritius. SPC Beche-de-Mer Information Bulletin 22: 48-52.

Morgan AD (2000). Aspects of the reproductive cycle of the sea cucumber Holothuria scabra (Echinodermata: Holothuroidea). Bulletin of Marine Science 66(1): 47-57.

Mumford SL (2004). Chapter 13 Histology of Finfish. USFWS, Olympia Fish Health Center, Olympia, Washington, 1-12 pp.

Pangkey H, Lantu S, Manuand L and Mokolensang J (2012). Prospect of sea cucumber culture in Indonesia as potential food sources. Journal of Coastal Development 15(2): 114-124.

Pitt R (2001). Review of sandfish breeding and rearing methods. SPC Beche-de-Mer Information Bulletin 14:14-21.

Purnama ER and Winarni D (2017). Fagocytosis of tuberculosis on mice after Phyllophorus sp. Treatments as Immunomodulator. BIOMA 1 (2): 105-114.

Purwati P and Luong-Van JT (2003). Sexual reproduction in a fissiparous holothurian species, Holothuria leucospilota Clark 1920 (Echinodermata: Holothuroidea). SPC Beche-de-Mer Information Bulletin 12: 11-14.

Ramofafia C, Battaglene S, Bell J and Byrne M (2000). Reproductive biology of the commercial sea cucumber Holothuria fuscogilva in the Solomon Islands. Marine Biology 136(6): 1045-1056.

Ramofafia C, Byrne M and Battaglene C (2003). Reproduction of the commercial sea cucumber Holothuria scabra (Echinodermata: Holothuroidea) in the Solomon Islands. Marine Biology 142(2): 281-288.

Revianti S, Soetjipto RPR and Parisihni K (2016). Protective role of Sticophus hermanii ethanol extract supplementation to oxidative stress and oral hyperkeratosis in smoking exposed rats. International Journal of Chemtech Research 9(05): 408-417.

Tuwo A (1999). Reproductive cycle of the holothurian Holothuria scabra in Saugi Island, Spermonde Archipelago, Southwest Sulawesi, Indonesia. INFOFISH International 6(97): 23-29.

Tuwo A (2005). Status of sea cucumber fisheries and farming in Indonesia. FAO Fisheries Technical Paper, $49-56$ pp.

Widianingsih W, Zaenuri M, Anggoro S, Kusumaningrum HP and Hartati R (2018). Preliminary study on gonad maturity stages of the sea cucumber Paracaudina australis from Kenjeran Water, Surabaya, Indonesia. IOP Conference Series: Earth and Environmental Science, 1-8 pp.

Winarni D, Khaleyla F, Damayanti H, Nugraha YF, Utami CS, Oktafiani D and Hayati A (2015). Reproductive peak, gonadal cycle and gametogenic cells determination of sea cucumber Paracaudina autralis from Madura Strait, East Java, Indonesia. International Journal of Academic Research 7(3A): 112-115.

Yudiati E, Hartati R and Suryono CA (2001). Kejut suhu dan salinitas pada spawning teripang hitam Holothuria edulis sebagai upaya peningkatan stock alami di perairan jepara, 1-17 pp. 